\title{
薬物の生体内動態からみたジクロフェナック （ボルタレン）の安全性について
}

$\begin{array}{lllll}\text { 加 藤 隆 一* } & \text { 野 口 } & \text { 英 世* } \\ \text { 土 屋 為 弘* } & \text { 寺 川 } \text { 雅 } \text { 人* }^{*}\end{array}$

ジクロフェナック（ボルタレン）は最近臨床分野で広 く使われている非ステロイド性鎮痛消炎剂であり，その 特徵は消化管における副作用が少ないことである. しか しラットおよびィヌでは他の市販されている非ステロイ ド系酸性消炎剂と同様に消化管毒性が強く, 3 力月の互 急性毒性試験では臨床用量に近い用量で消化管潰瘍およ び出血がみられた。しかし，サルでは 3 カ月の毒性試験 に打いて臨床用量の 40 倍を投与しても消化管潰瘍は認め られなかった。

そこでわれわれはジクロフェナックの臨床上での安全 性を確認するために, ラット, イヌ, サルおよびヒトで のジクロフェナックの生体内動態を比較検討し生体内動 態の差からこれら毒性の差異が説明できるか否かにつき 検討した。

一般的に多くの薬物の生物学的半減期はラットやイ ヌ よりもサルおよびヒトの方が長いといわれているにもか かわらず1), ジクロフェナックの血漿中半減期はサルお よびヒトでは短く, ラットやイヌの $1 / 2$ 1/3であった. すなわちジクロフェナックを静注した後の未変化体の血 漿中半減期を求めるとラットでは4.5時間, イヌでは3.5 時間, サルでは 2 時間でありヒトでは1.3時間であった。

また，静注後 2 時間目および 6 時間目での血漿中濃度 をイヌと, サルとで比べると, イヌの血漿中濃度の方が サルに比べて, 約10倍高く, 同様の結果は経口投与後の 血漿中濃度の比較においても認められた。すなわち、イ 又はサルに比べて血漿中濃度は高く, かつ消失速度も遅 いことがわかった。

ラットおよびイヌにジクロフェナックを静注後 6 時間 までの尿中総放射能排泄率は著しく低く, サルおよびヒ

*藤沢薬品工業株式会社 中央研究所
トでは比較的高く投与量の約 $40 \%$ であった。72時間目ま でにサルでは投与量の約 $76 \%$ が尿中に総放射能として排 泄され, 排泄率はサル, ヒト, イヌ, ラットの順で減少 し，イヌおよびラットの排泄率はサルの約1/2であった。

ラットでは静注後の尿中総放射能排泄率に比べて経口 投与後の方がやや高い值を示したが，サル，イヌおよび ヒトでは両者の間に大きな差は認められなかった。

サルでは末変化体の䔬中排泄率は低く投与量の $0.2 \%$ にすぎなかった。一方ラットおよびイヌでは高く，それ ぞれ投与量の $5 \%$ および21\%であった。72時間までにラ ットでは投与量の $66 \%$ ，イヌでは $53 \%$ が䔬中に総放射能

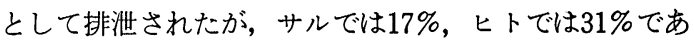
クラットやイヌの $1 / 2 \sim 1 / 3$ 排泄にすぎなかった.

したがって，ヒトおよびサルにジクロフェナックを投 与すると主として尿中に排泄され，他方，ラットおよび イヌでは主として霬中に排泄されることがわかった。

このように，尿および䔬中排泄がヒトおよびサルとラ ットおよびイヌの間で著しく異なることがわかったが, これは各動物種間で胆汁排泄が異なることに起因してい るのではないかと推察し、ラット，イヌおよびサルにつ いて胆汁排泄を検討した。

静注後の総放射能の累積胆汁中排泄率は各動物ともに 投与後 6 時間でほぼ一定となり, 以後ほとんど增えなか った. ラットでは投与量の $94 \%$ の総放射能が静注後 6 時 間に胆汁中に排泄された. イヌでは65\%であり，サルで は28\%であった。しかし，未変化体の排泄率は著しく低 く, ラットでは投与量の $0.1 \%$ ，イヌでは $0.4 \%$ ，そして サルでは0.2\%であり各動物ともに $1 \%$ 以下であった。 ラットでのジクロフェナックのアシルグルクロナイドの 胆汁中排泄率は投与量の $40 \%$ であり, イヌでは $56 \%$, サ 
表 $1{ }^{14} \mathrm{C}$ ージクロフェナック投与後の生物学的半減期および尿中, 胆汁中, 粪中排泄と 3 ヶ 月毒性との関係

\begin{tabular}{|c|c|c|c|c|c|c|c|c|}
\hline \multirow{2}{*}{ Animal } & \multirow{2}{*}{$\begin{array}{c}\text { Urinary }^{1)} \\
\text { excretion } \\
\begin{array}{c}\text { Total radio } \\
\text { activity }\end{array}\end{array}$} & \multicolumn{3}{|c|}{ Biliary $^{1)}$ excretion } & \multicolumn{2}{|c|}{ Fecal $^{2)}$ excretion } & \multirow{2}{*}{$\mathrm{T} 1 / 2^{3)}$} & \multirow{2}{*}{$\begin{array}{c}\text { Maximum } \\
\text { safety oral } \\
\text { dose for } 3 \\
\text { months }\end{array}$} \\
\hline & & Unchanged & $\begin{array}{l}\text { Acyl-gl- } \\
\text { ucuronide }\end{array}$ & $\begin{array}{c}\text { Total } \\
\text { radioactivity }\end{array}$ & Unchanged & $\begin{array}{c}\text { Total radio- } \\
\text { activity }\end{array}$ & & \\
\hline Rat & $7 \%$ & $0.1 \%$ & $40 \%$ & $94 \%$ & $5 \%$ & $56 \%$ & $4.5 \mathrm{hr}$ & $2 \mathrm{mg} / \mathrm{kg}$ \\
\hline Dog & 0.6 & 0.4 & 56 & 64 & 21 & 34 & 3.5 & 0.5 \\
\hline Monkey & 48 & 0.2 & 16 & 28 & 0.2 & 10 & 2.0 & $>50$ \\
\hline Man & 37 & 0 & - & - & - & 7 & 1.3 & - \\
\hline
\end{tabular}

1) $0-6$ 時間値

2） $0-24$ 時間值

3）未変化体の生物学的半減期

ルでは16\%であった.

このことは, 胆汁中の主排泄物はアシルグルクロナイ ドであり，イヌでは胆汁中に排泄された総放射能の $86 \%$ ， ラットでは42\%そしてサルでは59\%がアシルグルクロナ イドとして排泄されていることになる。

ラット，イヌ，サルともに静注後の総放射能の胆汁排 泄率と経口投与後の結果の間には大きな差は認められな かった.この結果と尿中排泄の結果を合わせて考劣ると, ジクロフニナックの消化管よりの吸収は良好に行われて いるものと思う.

一般のアシルグルクロナイドと同様にジクロフェナッ クのアシルグルクロナイドもアルカリに極めて不安定で あり $\mathrm{pH} 8$ 以上では容易にジクロフェナックに戻ること が確かめられた。 また，イヌに投与した後に集めた胆汁 をイヌの小腸または盲腸の内容物とインキュベーション すると容易にジクロフェナックを遊離することを確かめ た. とくにこの現象は盲腸内容物とインキュベーション すると著しかった。このことは胆汁中に排泄されたアシ ルグルクロナイドが消化管内に㨟いて非酵素的および $\beta$ グルクロニダーゼにより容易に加水分解を受けてジクロ フェナックに戻り, これが再び体内に吸収されて晹肝循 環の起こることを示唆している. 同様のことは総放射能 の胆汁排泄率に比べて挙中排泄率の低いことからもい兄 る. 胆汁排泄率の高いラットやイヌではサルに比べて腸

肝循環の起こる程度はより高いと考えられるので, ジク ロフェナックが消化管内扰よび体内により高い濃度で長 時間存在する傾向になるすのと考学られる。ヒトについ て胆汁排泄に関寸る直接的な知見は得られていないが, ジクロフェナックおよび代謝物の尿および䔬中排泄のデ 一ターのサルとの類似性から推定するとサルと同様にジ クロフェナックの腸肝循環はわりに少ないものと考兄ら れる.

これらの知見から, サルおよびヒトではジクロフェナ ックはすみやかに代謝され，主として尿中に排泄される のに対して，ラットおよびイヌではもっぱら胆汁中にそ の多くはアシルグルクロナイドとして排泄されることが わかった，胆汁中に排泄されたアシルグルクロナイドは 消化管内で水解されてジクロフェナックになり再び体内 に入り腸肝循環が起こるので胆汁排泄率の高いラットお よびイヌでは高濃度のジクロフェナックが消化管内およ び体内に比較的長時間存在するものと思われる.

以上の結果から, ジクロフェナックの生体内動態のラ ットおよびイヌとサルおよびヒトとの間の著しい美異 が, これら動物間における消化管毒性の発現の差異に関 連しているものと考えられる(表 1).

\section{文献}

1）加藤隆一; 現代の臨床, 5:308（昭46）. 